\author{
Андрей Дудчик \\ Уральский федеральный университет \\ им. первого Президента России Б. Н. Ельцина \\ Институт философии Национальной академии наук Беларуси \\ dudchik@philosophy.by \\ Andrei Dudchik \\ Ural Federal University \\ Institute of philosophy, National academy of sciences of Belarus \\ dudchik@philosophy.by
}

\title{
НОМОС БОЛОТА: КОНЦЕПТУАЛИЗАЦИЯ ПРОЕКТА БЕЛОРУССКОЙ «ПАРТИЗАНСКОЙ ЭТИКИ»1
}

\section{NOMOS OF THE SWAMP: CONCEPT OF THE PROJECT OF "PARTISAN ETHICS" IN BELARUS}

В работе реконструируются основные положения «партизанского мифа» в белорусской культуре послевоенного периода как важного элемента белорусской идентичности в области политической и хозяйственной жизни, коллективной и семейной памяти, системы образования и воспитания, массовой художественной культуры. Реконструируются особенности понимания «идеи партизана», имплицитно представленные в белорусских художественных произведениях военного и послевоенного периода. Демонстрируется интерес к этико-экзистенциальной проблематике, характерной для белорусского «партизанского нарратива»: для военного периода - тематика борьбы с врагом и идея отмщения, для послевоенного периода - идея индивидуального морального выбора в пограничной ситуации. Для обозначения партизанской деятельности в ситуации неопределенности и сопряженных с ней этических проблем предлагается использовать метафору «номос болота» по аналогии с терминами известного теоретика партизанской борьбы К. Шмитта и в силу значимости болотных образов для белорусской культуры.

Ключевые слова: этика партизана, теория партизана, партизанское движение, Великая Отечественная война, белорусская советская литература, белорусская идентичность.

The article reconstructs the main concepts of the "partisan myth" in the Belarusian culture of the post-war period as an important element of Belarusian identity in the

1 Исследование выполнено за счёт гранта Российского научного фонда (проект №20-18-00240). 
field of political and economic life, collective and family memory, the education system, mass culture. The peculiarities of understanding the "idea of a partisan", implicitly presented in Belarusian literature of the war and post-war period, are reconstructed. An interest in the ethical and existential issues as characteristic of the Belarusian "partisan narrative" is demonstrated: for the war period - the idea of fighting the enemy and the idea of a revenge, for the post-war period - the idea of an individual moral choice in a border situation. To designate partisan activity in a situation of uncertainty and ethical problems associated with it, it is proposed to use the metaphor "nomos of the swamp" by analogy with the terms of the famous theorist of partisan warfare C. Schmitt and due to the importance of swamp image for Belarusian culture.

Key words: partisan ethics, theory of the partisan, partisan movement, Great Patriotic War, Belarusian Soviet literature, Belarusian identity.

Понятия партизана, партизанской войны, партизанского движения достаточно активно используются для описания военных и политических событий XX - первой четверти XXI вв., к ним обращаются, в первую очередь, историки, специалисты в области военного дела и проблем безопасности. Как правило, понятие партизана и производные от него рассматриваются в более общем контексте т. н. «малых войн» наряду с близкими ему, но не тождественными понятиями участника герильи, террориста, представителя иррегулярных формирований (Freudenberg 2008: 251-254) и даже пирата и хакера (Мюнклер 2018: 300). В ХХ в. в ходе процессов деколонизации партизанские движения были представлены в разных частях света, в Европе и особенно в славянских странах деятельность партизан наиболее ярко проявилась в период Второй Мировой войны, при этом к партизанам в широком смысле относят как представителей антифашистского сопротивления, так и членов других иррегулярных формирований, в том числе - антикоммунистической направленности. И хотя партизанские движения были представлены практически во всех европейских странах, наиболее широкую известность и признание в рамках послевоенных политик памяти получила деятельность советских и югославских партизан. Советский нарратив о партизанской борьбе в целом рассматривался как составная часть общего нарратива о подвиге советского народа, тем не менее, внимание уделялось и партизанским движениям в отдельных советских республиках, особая роль при этом отводилась Белорусской ССР.

Это связано с масштабной деятельностью партизан на белорусской территории в период 1941-1944 гг., активным участием бывших партизан в послевоенной политической и хозяйственной жизни (так, М. Урбан отмечает, что важным для политической карьеры в республиканском и общесоюзном масштабе были опыт относительно автономной от центральных властей партизанской деятельности (Urban 1989: 13-14)), формированием в послевоенные годы белорусского «партизанского мифа», рассматривавшего события Великой Отечественной войны и непосредственно деятельность партизанского движения как центральные в новейшее белорусской истории и конститутивные для советской белорусской 
государственности (международный статус республики как члена-основателя Организации Объединенных Наций, высокое положение во внутрисоюзной неформальной иерархии), широкой представленностью партизанской тематики в официальной художественной культуре - прежде всего, художественной литературе и игровом кино (республиканская киностудия «Беларусьфильм» получила неофициальное наименование «Партизанфильм») - и топонимике. В целом партизанская тематика была одним из центральных элементов нарратива о страданиях и подвигах белорусского народа. Форма и содержание белорусского «партизанского мифа» позволяла акцентировать национальные особенности, не вступая в противоречия с общесоветским военным нарративом (Urban 1989: 13-14). В целом же, как отмечают исследователи, апелляция к локальным идентичностям, к региональному патриотизму была характерна для советского партизанского движения и в других регионах (Литвинова 2016: 301).

В постсоветский период в официальной исторической политике сохранился высокий интерес к теме Великой Отечественной войны (например, появились обязательные спецкурсы в высших учебных заведениях (Коваленя 2004)), при этом существенное внимание уделяется тематике партизанского движения, (например, в 2019 г. было издано соответствующее энциклопедическое издание (Литвин 2019) а в 2020 г. - создан специальный интернет-ресурс (Партизаны Беларуси 2021) и разработан комплект стикеров для общения в интернет-мессенджерах (Партизанский стикерпак 2021)). Представители оппозиционных взглядов (со всей условностью данного термина) пытаются критически относиться к официальному образу партизанского движения, например, издавая переводы зарубежных критических исследований по партизанской тематике (Бартушка 2014: 67-109; Мусял 2018). Вместе с тем происходит и постепенная апроприация советского партизанского нарратива, интерпретация его как аутентично-белорусского, нахождение его признаков в более ранних периодах белорусской истории и понимание партизанскости как формы белорусской идентичности и культурного сопротивления (Льюис 2020). В частности, партизанский нарратив активно использовался обеими сторонами в период политических протестов в Беларуси во 2-й половине 2020 г.

Сама тематика партизанской борьбы была представлена и в белорусской советской литературе довоенного периода, в основном она была связана с событиями гражданской войны, советско-польской войны, а также с борьбой белорусского национального движения на западнобелорусских землях, входивших в состав Польши: здесь следует вспомнить повесть классика белорусской литературы Якуба Коласа (Константин Михайлович Мицкевич, 1882-1956) Трясина (1933) и его же стихотворение «Партизанская песня» (1937), повесть Михася (Михаила Тихоновича) Лынькова (1899-1975) Миколка-паровоз (1936). 
Если говорить о периоде Великой Отечественной войны, то наиболее полно нормативная концепция партизанского поведения дается в военных произведениях классика белорусской литературы Янки Купалы (Ивана Доминиковича Луцевича, 1882-1942), посмертно изданных в 1942-м в виде брошюры под общим названием Белорусским партизанам (по названию одноименного стихотворения, получившего широкую известность в военное время, в том числе - в качестве текста листовок и плакатов). Брошюра содержит небольшую статью и 5 стихотворений, посвященных тематике войны. Все тексты призывают к беспощадной борьбе с врагом, который представлен коллективно - как немецкие фашисты, и персонально - как А. Гитлер. О причинах войны Купала пишет вполне определенно: «Так же скажем и мы, белорусы. Пролилась кровь наших жен, детей, матерей и отцов... нашей вины в начавшейся войне нет» (Купала 1942b: 9). В текстах используются радикальные характеристики врагов: фашистские варвары, фашистский стервятник, фашистский вампир, трусливые убийцы, фашистские палачи, людоеды, фашистов собачий род, трупоед и т. д. В леденящих подробностях описываются их деяния на захваченных территориях: они грабят хозяйства; насилуют женщин; как скотину, режут людей и т. д. При этом перечисляются не только обиды и преступления против белорусов и советского народа в целом, но и против других стран: «ограбили и пустил с нищенской сумой Польшу», «расклевал на части Чехословакию», «солнечную Грецию утянул во тьму», «норвежской кровью залил норвежские фьорды» и т. д. Фигура врага-фашиста, и, соответственно, процесс беспощадной борьбы с ним абсолютизируется, принимает всемирный масштаб подлинно политической беспощадной борьбы.

Как пишет Купала, ссылаясь на слова Сталина: «Да, это не обычная война. Война разума против безумия, свободы - против каторги, человека — против зверя» (Купала 1942b: 9). Образ врага в значительной степени утрачивает человеческие черты, выступая в качестве фантастических персонажей: вампира-кровопийцы, людоеда, трупоеда, гадюки, заразы и т. д., против которых необходимо использовать сверхъестественные средства, чтобы они «никогда не воскресли»: осиновый кол, традиционное народное прокялтье (Алейчанка 2019: 5). «Пусть наш хлеб в глотке кровожадного врага превратится в раскаленное железо, пусть вода из живых источников будет для зверей-людоедов отравой и слепит их кровавые глаза» (Купала 1942с: 15). Отдельно поэт обращается к образу А. Гитлера («прусского фюрера, трупоеда, грабителя», «присяжного вешателя, царя скотского разгула») которого он несколько раз призывает повесить (в том числе - на сухом осиновом дереве, на котором, в соответствии с народными представлениями, повесился Иуда Искариот), чтобы «Гитлеру-вампиру [вороны] клевали сердце, сосали кровь, раз он был сыт человечьим жиром, был пьян кровавым безумием, пусть же погибнет зверь зверей» (Купала 1942a: 11). С советской стороны Гитлеру 
противопоставляется фигура другого вождя - И. В. Сталина, который внимательно следит за деятельностью партизан, направляет их и ободряет. В тексте фигурирует также упоминание «Сталинской» Конституции 1936 г., «под солнцем которой вновь будет счастлива Беларусь» (Купала 1942b: 10) и которая символизирует мирное и упорядоченное состояние, нарушенное войной. В изданиях стихотворений Купалы после 1956 г. фрагменты, содержащие упоминание о Сталине, как правило, отсутствуют. В целом образ врага, который создается в художественных текстах, близок фигуре «абсолютного врага» в понимании К. Шмитта, а борьба с этим врагом приобретает самый радикальный характер. Как пишет сам Шмитт в своей известной работе о понятии политического: «Война как самое крайнее политическое средство обнаруживает возможность этого различения друга и врага, лежащую в основе всякого политического представления, и потому имеет смысл лишь до тех пор, пока в человечестве реально наличествует или, по меньшей мере, реально возможно это представление... войны, по необходимости, особенно интенсивные и бесчеловечные, ибо они, выходя за пределы политического, должны одновременно умалять врага в категориях моральных и иных и делать его бесчеловечным чудовищем, которое надо не только отразить, но и окончательно уничтожить, то есть он перестает быть всего лишь врагом, подлежащим водворению обратно в свои границы» (Шмитт 2016: 311-312). И хотя в стихах Купалы речь ведется преимущественно о партизанской борьбе против фашистов на своей земле и с целью ее защиты, в них можно найти и указание на необходимость продолжения борьбы на чужой территории. В частности, в стихотворении из сборника Белорусским партизанам «Мальчик и летчик на войне», которое является продолжением известного «мирного» стихотворения Купалы 1935 г., речь идет не только о том, чтобы «освободить из плена родной край», но и о том, чтобы «заглянуть в глаза Берлину» и «сбросить Гитлеру веревку, чтобы палач быстрее повесился» (Купала 1942d: 18). В текстах Купалы упоминается ряд народов, выступающих союзниками белорусских партизан: это «великий русский народ», на чьи традиции партизанской войны 1812 г. несколько раз ссылается автор в тексте, украинский народ («потомки Богдана Хмельницкого, доблестные воины Советской Украины» (Купала 1942b: 8)), а также - «соколиное партизанское движение в родной по крови Югославии» (Купала 1942b: 9), и, в частности, сербские партизаны. К. Шмитт в своей работе Теория партизана в качестве одной из отличительных особенностей партизанского движения XX в., отличающей его от партизан более раннего периода, называет его политическую вовлеченность, и, в частности, тесную связь с политическими партиями (как новыми и главными действующими силами мировой политики, претендующими на воплощение политической тотальности и использующими исходный импульс партизанской борьбы в своих целях всемирной борьбы и революции). Он пишет, что 
«Сталину во время Второй Мировой войны удалось соединить теллурическое национально-почвенническое партизанство с классовой враждой интернационального коммунизма» (Шмитт 2007: 93). Тем не менее, в анализируемых текстах мы не встречаем акцента на классовой принадлежности врагов, не упоминаются и партийные органы (только непосредственно Сталин и «Сталинская» конституция). Скорее, идеология, представленная в этих текстах ближе к тому, что Д. Бранденбергер обозначает как «национал-большевизм» с акцентом (возможно - ситуативным (Бранденбергер 2009: 326)) на величии белорусского народа как братского по отношению к «великому русскому народу».

В качестве возмездия за совершенные злодеяния поэт призывает к достаточно радикальным действиям: «режьте», «вырезайте», «ройте заранее могилы», «вырывайте жилы из живых», «уничтожайте», «будем давить их, как вшей, как гадких вонючих клопов» и т. д. Подобная установка воспроизводит призыв, озвученный Сталиным в его выступлении по радио 3 июля 1941 г.: «в захваченных районах создавать невыносимые условия для врага и всех его пособников, преследовать и уничтожать их на каждом шагу, срывать все их мероприятия» (Слава советским партизанам! 1941: 4). Столь же радикально описывает поэт и отношение к останкам убитых врагов, он призывает отдать их кости птицам, чтобы не осталась их и следа «на нашей святой земле», что еще раз подчеркивает их нечеловеческую сущность. Таким образом, Купала прямо призывает к мести по отношению к врагам, что является достаточно общим местом для белорусской военной поэзии того периода, например, Я. Колас в 1942 г. публикует стихотворную брошюру Отомстим (содержащую одноименное стихотворение), в которой также содержатся призывы очистить землю от нелюдей, отрубить врагу голову, забить ему в сердце осиновый кол и т. п. (Колас 1942) В своих текстах Купала прямо отсылает к морально-правовому принципу талиона (lex talionis), предполагающему симметричное возмездие за совершенные деяния и в философии права относимому к воздающему или ретрибутивному типу справедливости. Широко известные формулировки принципа талиона воспроизводятся в текстах дословно: «Око - за око, зуб - за зуб ответим мы фашистам, не дадим им ни отдыха, ни срока» (Купала 1942b: 8), «кровь за кровь, и смерть за смерть» (Купала 1942а: 13). Те же идеи в торжественно-официальной форме представлены в тексте «Присяга белорусского партизана», которая начинается словами «Кровь за кровь, смерть за смерть!»:

«За сожженные города и села, за смерть детей наших, за пытки, насилия и издевательства над моим народом я клянусь мстить врагу жестоко, беспощадно и неустанно.

Кровь за кровь и смерть за смерть! 
Я клянусь всеми средствами помогать Красной армии уничтожать бешеных гитлеровских псов, не щадя крови и своей жизни.

Я клянусь, что скорее умру в жестоком бою с врагом, чем отдам себя, свою семью и весь белорусский народ в рабство коварного фашизма» (Присяга белорусского партизана 1941: 3).

Как видно из последнего предложения, как и большинство клятв, текст присяги партизана содержит т.н. виндиктивную составляющую, т. е. указывает на готовность подвергнуть себя каре в случае нарушения высказываемого (Чесноков 2016: 110): «Если же по моей слабости, трусости или по злой воле я нарушу эту свою присягу и предам интересы народа, пусть умру я позорной смертью от руки своих товарищей» (Присяга белорусского партизана 1941: 3).

В дальнейшем различные варианты этого текста публиковались в прессе, использовались в партизанских отрядах на русском и белорусском языках. Присяга партизана выступала основным регулятором поведения и поддержания дисциплины в партизанских отрядах (Кулик 2006: 58). Сравнительный анализ показывает достаточно большую степень сходства присяги белорусских партизан и аналогичных присяг других советских партизан (Клятва курских партизан... 1942; Клятва партизан отряда им. «Павла»... 1941; Клятва, дававшаяся партизанами Одесского Пригородного района... 1942), в большинстве из которых также делается акцент на отмщении, здесь же можно вспомнить распространенное именование партизан «народными мстителями».

Интересно отметить, что стихотворения Купалы с призывами покарать врагов были опубликованы осенью 1941 г. (кроме «Вновь будем иметь счастье и волю» - 1942 г.), т. е. ранее, чем известные работы схожей направленности К. М. Симонова «Убей его» (Симонов 1942) и И. Г. Эренбурга «Убей!» (Эренбург 1942). Можно предположить, что те действия и чувства, к которым призывает Купала партизан с начала войны, для солдат регулярной армии - основных адресатов произведений Симонова и Эренбурга - оказываются приемлемыми только в критических обстоятельствах лета 1942 г., одного из наиболее тяжелых периодов для Красной Армии. Как отмечает известный российский этик Р. Г. Апресян «талион - последняя возможность сохранения человечности в неприспособленных для человечности обстоятельствах подобных тем, что передаются нормативной моделью «войны всех против всех», не важно, понимается ли эта модель как метафора или дескриптивно достоверная концепция» (Апресян 2001: 82). Вероятно, в случае регулярных боевых действий метафору «войны всех против всех» можно трактовать как особую степень радикализации и интенсификации боевых действий. Для партизанской же войны, как будет показано далее, данная характеристика может восприниматься и более буквально. 
Исследователи истории нравственных систем рассматривают принцип талиона как один из ранних вариантов нравственного ограничения и регулирования насилия, функционально сходный с государственными законами и специальными профессиональными нормами воинского этоса (Беляева 2018: 209). Обращение к нормам талиона в ситуации кризиса советских властных институций (оккупация) и наличия иррегулярных боевых формирований выглядит достаточно понятным.

Основной субъект акта мести в произведениях Купалы - коллективный, идет обращение к партизанам как к некоему целому — «белорусским сынам», мужам и отцам), и хотя напрямую партизаны таким образом не называются, но указывается на необходимость защиты жен и детей, а также отмщение за насилие по отношению к ним. В текстах Купалы и Коласа партизаны явным образом гендерно маркированы в качестве мужчин, но в сборнике Партизаны Великой Отечественной войны советского народа 1941 г. содержится ряд текстов, в которых описываются партизанские действия детей и стариков: «среди них есть крестьяне, сражавшиеся в партизанских отрядах двадцать три года тому назад. Это - профессора партизанства. Среди партизан есть и ребята. Армия дедов и внуков» (Эренбург 1941: 16), «головы женщин аккуратно повязаны платками, в руках у них вилы и топоры - оружие, которым они бились с врагом и которое они пронесли сквозь леса и болота» (Габрилович 1941: 24). Интересно отметить, что в воспоминаниях женщин-участниц партизанского движения можно найти схожую мотивацию - желание «отомстить за насилие, совершенное фашистами над ее семьей, друзьями, соседями и знакомыми» (Вальке 2011: 142). Фактически, в качестве потенциального партизана рассматривается каждый белорус, независимо от возраста и пола: «пока будет жив хоть один белорус не будет на белорусской земле покоя фашистским захватчикам, горькой будет их жизнь, с каждого дерева, из каждого оврага будут следить за ними внимательные партизанские глаза» (Купала 1942b: 9). Можно предположить, что это соотносится как с коллективистскими установками официальной советской культуры (образ белорусского народа), так и с представлениями об общинном коллективном субъекте талиона («теле рода» (Грякалов 2015: 15)), локальном сельском сообществе знакомых людей. Вероятно, в данном случае можно предположить соединение элементов традиционных и современных («модерных») этических представлений, до сих пор в определенной мере характерных, по мнению специалиста в области этики Е. В. Беляевой, и для белорусского общества начала XXI в. (Беляева 2013).

Обратившись к описанию войны и конкретно партизанского движения в послевоенной белорусской литературе, мы столкнемся с целым рядом существенных изменений. Наиболее ярко они проявляются в творчестве классика белорусской литературы, писателя-фронтовика Василя (Василия Владимировича) Быкова (1924-2003). Исследователи его твор- 
чества часто отмечают близость его произведений работам писателейэкзистенциалистов: в них ставится проблема нравственного выбора человека в драматических и неоднозначных обстоятельствах войны. Наряду с боевыми действиями на передовой, деятельность партизан одна из наиболее частых тем в творчестве Быкова. Если сравнить его произведения с рассматриваемыми ранее текстами военного времени, прежде всего, обращает на себя внимание в изменении образа врага. Вместо вполне однозначного образа немецкого фашиста в произведениях Быкова часто фигурируют люди, в тех или иных формах сотрудничающие с оккупантами, от коллаборантов и полицейских, с оружием в руках, выступающих на стороне оккупационных властей, до людей, занимающихся хозяйственной или административной деятельностью с санкции оккупантов. При этом их мотивация к сотрудничеству с оккупантами может быть достаточно разной, многие объясняют это необходимостью выбирать меньшее из зол, многие из них в той или иной форме тайно поддерживают партизан. Особенно подчеркивается, что многие из сотрудничающих до войны были вполне лояльными советскими гражданами и пользовались симпатией и уважением со стороны соседей (ср. с идеями Х. Арендт о «банальности зла» (Арендт 2008)). При этом выбор одной из сторон противостояния не всегда является однозначным и одномоментным, он часто сопряжен с внутренними поисками и неоднозначен по своим последствиям. Отсутствие униформы, которое выделяется Шмиттом как важный признак иррегулярности деятельности партизана (Беседа о партизане 2007), обыгрывается в произведениях Быкова как элемент неопределенности, когда при столкновении с незнакомым человеком проблематично дать быстрый однозначный ответ, кто это: партизан или полицейский («полицай».).

Российский исследователь О. Хархордин, основываясь на исследованиях исповедальных практик М. Фуко, пишет о значимости публичного коллективного обсуждения для становления субъективности советского человека (Kharkhordin 1999). В произведениях Быкова подобные функции выполняют сцены допроса, которые также демонстрируют изощренную диалектику правды и лжи и высокую степень рефлексивности по отношению к проговариваемому, а также ставят фундаментальные вопросы экзистенциального характера. Важно отметить, что в партизанских отрядах также большую роль играли коллективные собрания, выполнявшие важные дисциплинарные функции: «применялись все меры дисциплинарного воздействия согласно соответствующим уставам и положениям Красной Армии. Большое значение имело общее собрание отряда, на котором разбирались провинившиеся партизаны» (Кулик 2006: 59). Гипотетическая ситуация допроса со стороны фашистов, которым не следовало выдавать секретные сведения (часто - о местонахождении солдат или партизан) была распространена в послевоенной советской культуре как своеобразный мысленный эксперимент, прове- 
ряющий человека на стойкость убеждений и силу моральных качеств. В качестве примера можно вспомнить стихотворение белорусского поэта-фронтовика Аркадия Александровича Кулешова (1914-1978) «Комсомольский билет», в котором рассказывается как «парень держался, был твёрд на допросе, Мысли держал и слова при себе»². Впрочем, данный сюжет встречается и в довоенной советской литературе, например, сцена допроса Мальчиша-Кибальчиша в повести Аркадия Петровича Гайдара (Голикова, 1904-1941) «Военная тайна» (Гайдар 1959). В повести Быкова Сотников реальный допрос партизана фашиста чередуется с воспоминанием из детства, в котором главный герой вынужден признаваться отцу, что без спросу брал его боевое оружие. Но в случае допроса партизана, против которого отсутствуют очевидные доказательства, ситуация становится более сложной и рефлексивно изощренной. Таким образом, можно предположить, что ситуация допроса, ставящая перед героем проблему непростого и неоднозначного морального выбора, способствовала становлению идентичности и субъективности.

Современные исследователи партизанского движения в Восточной Европе отмечают его связь и обусловленность особенностями регионального ландшафта, существенно отличающимися от более урбанизированного западноевропейского ландшафта - «недоосвоенные сельские территории с густыми лесами, раскинувшимися болотами и высокими горными хребтами» (Shepherd, Pattinson 2010: 2). Белорусские территории до сих пор изобилуют лесами и болотами, Беларусь исторически является одной из наиболее увлажненных стран Европы, а процессы мелиорации осуществлялись на протяжении XIX-XX вв., особую интенсивность приобретя в послевоенный период (Желязко, Лагун, Лихацевич 2016: 75-77). Образ болот и тематика жизни на болоте широко представлена в белорусской литературе довоенного периода, в том числе и в связи с деятельностью партизан. В качестве примера можно привести уже упоминавшуюся ранее повесть Я. Коласа Трясина, посвященную партизанской борьбе в период советско-польской войны, центральным персонажем произведения является реально существовавший человек Василий Исаакович Талаш («Дед Талаш», 1844-1946), впоследствии ставший партизаном и в период Великой Отечественной войны. Болото и лес, наряду с деревней - наиболее распространенные локации, описывающиеся в произведениях, посвященных партизанской тематике. Интересно отметить, что термин «Лесные братья», непосредственно связывающий партизанскую вооруженную борьбу с лесом устойчиво ассоциируется с антисоветскими формированиями, действовавшими как на территории Беларуси, так и в других странах регионах. Соответ-

2 В данном случае используется вариант перевода на русский язык В. Кабердина, который ближе к белорусскому оригиналу и лучше отражает мысль о сокрытии внутренней жизни во время допроса (Кулешов 2011). 
ственно, советские партизаны могли бы быть названы «Люди на болоте» - по названию романа (1962) белорусского писателя Ивана Павловича Мележа (1921-1976), посвященного довоенной жизни полесской деревни (Мележ 1991). Конечно, ни реальные партизаны, ни их литературные образы не действовали исключительно на болотах, однако труднодоступность болот, дополнительные сложности и опасности передвижения по болотной местности часто использовались партизанами как дополнительный элемент защиты и маскировки. Более того, рискну предположить, что образ болота может быть рассмотрен как эвристически нагруженная метафора для описания партизанской деятельности в целом, а также для характеристики ряда этических моментов, связанных с партизанским движением.

С изучением феномена партизанства достаточно тесно связано понятие номоса, используемое К. Шмиттом для обозначения определенного упорядочивающего принципа, связанного со взаимодействием человека и природного ландшафта. Сам Шмитт пишет об основополагающем для европейского международного права «Номосе Земли», регулировавшем отношения между государствами и нормировавшем порядок ведения боевых действий. Современные же войны, и, прежде всего, деятельность партизан очевидным образом не вписываются в эти нормативные рамки и ставят сложившийся порядок под сомнение. В качестве важной черты партизана Шмитт выделяет его «теллуричность», т. е. связь с определенной территорией, которую партизан защищает. Вместе с тем ряд новых особенностей партизанской деятельности, таких как ее мобильность, поддержка третьими силами, использование современной техники также ставят под вопрос характер связи партизана с землей (Куренной 2008: 277-278). Партизан, пишет Шмитт, «добавляет поверхности регулярного, обычного театра военных действий другое, более темное измерение, измерение глубины» (Шмитт 2007: 107). И, далее, он приводит «неожиданную, но от этого не менее эффективную аналогию с подводной лодкой» (Шмитт 2007: 108). И хотя далее автор пытается провести строгое различие между сушей и морем и настаивает на исключительно земной, теллурической сущности партизана, все же сложно отделаться от представления об определенном синтезе принципов моря и земли в деятельности партизан.

Неожиданный эвристический эффект здесь может выполнить метафора еще одного теоретика партизанской борьбы, Мао Цзэдуна (18931976), который «сравнивал партизан с “рыбой”, плавающей в “море”, которое представляет собой весь остальной народ. Смысл данного сравнения состоит именно в том, что море не обладает качествами, отличающими одну его часть от другой» (Ван Кревельд 2005: 309). При этом стоит отметить, что рыба может водиться не только в море или реке, но и на болоте, в глубинах которого также можно спрятаться. Болото, в свою очередь, как бы соединяет элементы земной и водной стихий, 
одновременно скрывая за спокойной поверхностью глубину и непредсказуемость. В традиционной белорусской культуре болото рассматривалось как беспорядочная смесь воды и земли, первоэлементов, из которых в дальнейшем был создан Космос, болото воспринималось как опасное место, населенное нечистью (Дучыц, Лобач, Санько 2004: 41-42). Важная характеристика болота - его зыбкость, отсутствие твердой почвы под ногами, оно представляет собой, используя заглавие известной книги Льва Исааковича Шестова (Иегуды Лейб Шварцмана, 1866-1938), «апофеоз беспочвенности» (Шестов 2018). В принципе, подобные аналогии вполне уместны по отношению к идеям Шмитта, чью позицию исследователи сравнивают с «политическим экзистенциализмом» (Wolin 1990), а фигуру партизана рассматривают как «пронзительный пример лишенности политической основы» (Marder 2010).

Неожиданно философски нагруженную интерпретацию метафоры болота предлагает Ф. Ницше: «Требование "свободы воли” в том метафизическом, раздутом смысле... желание самому нести всю без изъятия ответственность за свои поступки, сняв ее с Бога, с мира, с предков, со случая, с общества, есть не что иное, как желание быть той самой causa sui и с более чем мюнхгаузеновской смелостью вытащить самого себя за волосы в бытие из болота Ничто». Любопытным образом пересекается с этой сентенцией фрагмент из повести «Сотников», описывающей бегство героя из немецкого плена: «Не обращая внимания на опять раздавшиеся выстрелы, а также ветки, раздиравшие его лицо, он долго бежал, пока не забрался в болото. Деваться было некуда; и он влез в кочковатую, с окнами стоячей воды трясину, из которой уже никуда не мог выбраться. Там он понял, что если не утонет, то может считать себя спасенным. И он затаился, до подбородка погрузившись в воду и держась за тоненькую, с мизинец, лозовую ветку, все время напряженно соображая: выдержит она или нет. Если бы ветка сломалась, он бы уже не удержался, силы у него не осталось. Но ветка не позволила ему скрыться с головой в прорве, мало-помалу он отдышался и, как только вдали затихла стрельба, с трудом выбрался на сухое» (Быков 1985: 368). В определенном смысле заход на территорию болота может быть рассмотрен как готовность подвергнуть свою жизнь опасности. Например, в рассматриваемой ранее статье Купалы автор пишет, как в начале войны «женщины уносили маленьких детей - Пусть лучше в болоте погибнет, чем достанется немецким фашистам» (Купала 1942b: 5).

Интересно отметить, что в своих поздних произведениях Быков часто обращается к образу болота. Одна из его повестей так и называется - Болото. В ней описывается, как группа советских военнослужащих забрасывается в тыл чтобы встретиться с партизанами, однако с самого начала их сбрасывают не в условленном месте и на протяжении всего произведения они находятся в ситуации неопределенности по отношении к местам, в которые они попали, людям, с которыми они встречаются 
(командир группы отдает приказание убить местного мальчика, который показал им дорогу к партизанам, поскольку не уверен, не сообщит ли тот об этом врагу), да и самим себе (по мере повествования мы узнаем непростые подробности прошлого действующих лиц), заканчивается все трагически - группа попадает под дружественный огонь своих партизан. «Все, что ни повидится ночью, на деле - причудливое и фальшивое. Ночью каждый куст кажется загадочным, каждое пятно издали таит в себе подозрительный знак. Вернее в ночи слух, но и он нередко подводит, выдавая кажущееся за действительное» (Быков 2001). Столь философски нагруженное описание подчеркивает сложность партизанской активности, которая постоянно ставит под сомнение казавшиеся вполне очевидными представления о мире, в том числе и морального характера - оказывается сложным найти обоснование для своих действий в представлениях из области мирной жизни или официальных предписаниях. Партизан, поставленный в чрезвычайные условия, оказывается вынужден на свой страх и риск пробираться через метафорическое болото, постоянно ища для себя опору и основание.

Таким образом, можно сделать вывод, что как для военного, так и для послевоенного периода для «идеи партизана», ярко представленной в белорусской советской литературе и ставшей одной из основ для формирования белорусской идентичности, характерен акцент на морально-экзистенциальной проблематике. Для литературы военного периода (на примере произведений Я. Купалы) характерна идея исторической борьбы с врагом, образ которого приобретает нечеловеческие черты абсолютного врага, моральным основанием борьбы выступает идея отмщения в соответствии с принципом талиона. Основным деятельным субъектом выступает коллектив. Для послевоенного периода (на примере произведений В. Быкова), напротив, характерен акцент на индивидуальном моральном опыте и личном выборе в экзистенциальной ситуации. Для концептуализации партизанской деятельности в ситуации неопределенности и сопряженных с ней этических проблем предлагается использовать метафору «номос болота», развивающую терминологию известного теоретика партизанской борьбы К. Шмитта.

\section{ЛИТЕРАТУРА}

Алейчанка Юлія. «Апошняе сказанае»: рытм і сэнс лірыкі Янкі Купалы 1941-1942 гг.». Мова і літаратура: матэрыяль 76-ц̆ навук. канф. студэнтаў і аспірантаў філалагічнага фак. БДУ, Мінск, 24 красавіка 2019 г. [пад рэд. К. А. Тананушкі]. Мінск: БДУ, 2019: 3-6.

Апресян Рубен. «Талион и золотое правило: критический анализ сопряженных контекстов». Вопросы философии 3 (2001). 72-84.

Арендт Ханна. Банальность зла. Эйхман в Иерусалиме. Москва: Европа, 2008.

Бартушка Марк. Партызанская вайна у Беларусі ў 1941-1944 г2. / Марк Бартушка. Смаленск: Інбелкульт, 2014. 
Беляева Елена. «Историческое формирование универсалий морали». Мораль и универсальность: сб. науч. ст. под ред. Р. Г. Апресяна. Москва: Гуманитарий. 1 (2018): 195-212.

Беляева Елена. «Неотрадиционализм как характеристика системы нравственности белорусского общества». Вучоныя запіскі Брэсикага універсітэта: зб. навук. прац. 9. Частка 1. Гуманітарныя і грамадскія навукі, 2013: 15-21.

«Беседа о партизане». Карл Шмитт и Иоахим Шикель. Теория партизана. Москва: Праксис, 2007: 145-178.

Браденбергер Давид. Национал-Большевизм. Сталинская массовая культура и формирование русского национального самосознания (1931-1956). Санкт-Петербург: Академический проект - Издательство ДНК, 2009.

Быков Василь. Болото. Дружба Народов 7 (2001) https://magazines.gorky.media/ druzhba/2001/7/boloto.html 08.05.2021.

Быков Василь. Сотников. Быков Василь. Собрание сочинений. В 4 т. Т.2. Москва: Молодая гвардия, 1985: 305-452.

Вальке Аника. «Память, гендер и молчание: устная история в (пост-) советской России и призрачная грань между публичным и приватным». Laboratorium. Журнал социальных исследований 1 (2011): 138-154.

Ван Кревельд Мартин. Трансформация войныл. Москва: Альпина бизнес букс, 2005.

Габрилович Евгений. «Героические женщины белорусского народа» Наумова А. (ред.). Партизаны Великой Отечественной войны советского народа. Москва - Ленинград: Детгиз, 1941: 21-24.

Гайдар Аркадий. Военная тайна. Пермь: Пермское книжное издательство, 1959.

Грякалов Николай. «Lex talionis. К фундаментальной антропологии талиона». Вестник Санкт-Петербургского университета. Философия и конфликтология 2 (2015): $12-20$

Дучыц Людміла, Лобач Уладзімір, Санько Сяргей. «Балота». Беларуская мифалогия. Беларуская міфалогія: Эниыклап. слоўнік. Мінск: Беларусь, 2004: 41-42.

Желязко Владимир, Лагун Тихон, Лихацевич Анатолий «Развитие сельскохозяйственной гидромелиорации в Беларуси». Природообустройство 4 (2016): 75-80.

«Клятва курских партизан на верность Родине, советскому народу, правительству и Коммунистической партии. 12 октября 1942 г.» < http://docs.historyrussia.org/ru/ nodes/248943-klyatva-kurskih-partizan-na-vernost-rodine-sovetskomu-narodupravitelstvu-i-kommunisticheskoy-partii-12-oktyabrya-1942-g>09.05.2021.

«Клятва партизан отряда им. «Павла» Шаховского района Московской области. Октябрь 1941 г.»<http://docs.historyrussia.org/ru/nodes/178061-klyatva-partizan-otryadaim-pavla-shahovskogo-rayona-moskovskoy-oblasti-oktyabr-1941-g> 09.05.2021.

«Клятва, дававшаяся партизанами Одесского Пригородного района при вступлении в отряд. Январь 1942 г.»<http://docs.historyrussia.org/ru/nodes/181012-klyatvadavavshayasya-partizanami-odesskogo-prigorodnogo-rayona-pri-vstuplenii-v-otryadyanvar-1942-g>09.05.2021.

Коваленя Александр, Сташкевич Николай. Великая Отечественная война советского народа (в контексте Второй мировой войны). Минск: Издательский центр БГУ, 2004.

Колас Якуб. Адпомсцім. Масква: Выданне газеты «Совеикая Беларусь», 1942.

Кулешов Аркадий. «Комсомольский билет» <https://stihi.ru/2011/11/07/9898>/ 07.05.2021.

Кулик Сергей. «Категории партизанских отрядов в годы Великой Отечественной войны». Вестник Новгородского государственного университета им. Ярослава Мудрого 37 (2006): 58-60.

Купала Янка. «Беларускім партызанам». Беларускім партызанам. Масква: Выданне газеты «Совецкая Беларусь», 1942: 11-14.

Купала Янка. «Паднялася Беларусь». Беларускім партызанам. Масква: Выданне газеты «Совецкая Беларусь», 1942: 5-10. 
Купала Янка. «Паўстаў народ». Беларускім партызанам. Масква: Выданне газеты «Совецкая Беларусь», 1942: 15-16.

Купала Янка. «Хлопчык і лётчык на вайне». Беларускім партызанам. Масква: Выданне газеты «Совецкая Беларусь», 1942: 17-18.

Куренной Виталий. «Теория партизана». [Рец. на книгу: Шмитт К. Теория партизана. Москва: Праксис, 2007]. Неприкосновенный запас 1 (2008): 275-278.

Литвин Алексей (ред.). Беларусь партизанская. Иллюстрированная энциклопедия партизанского движения в Беларуси в годы Великой Отечественной войны. Минск: Беларуская Энцыклапедыя імя Петруся Броўкі, 2019.

Литвинова Ольга. «Эволюция партизанской этики в годы Великой Отечественной войны (по материалам Брянщины)». Ярославский педагогический вестник 1 (2016): 297-302.

Льюис Саймон. «“Партизанская республика”: колониальные мифы и война за память в Беларуси». Новое литературное обозрение 6 (2020) <https://www.nlobooks.ru/ magazines/novoe_literaturnoe_obozrenie/166_nlo_6_2020/article/22957/> 09.05.2021.

Мележ Іван. Людзі на балоце: раман з «Палескай хронікі». Мінск: Мастацкая літаратура, 1991.

Мусял Богдан. Савеикія партызаны у 1941-1944 г2. Міфы і рэчаіснасиь. Смаленск: Інбелкульт, 2018.

Мюнклер Герфрид. Осколки войны. Эволюиия насилия в XX и XXI веках. Москва: Кучково поле, 2018.

Ницше Фридрих. По ту сторону добра и зла. Ницше Фридрих. Полное собрание сочинений. В 13 т. Т. 5. Москва: Культурная революция, 2012: 9-228.

Партизанский стикерпак <https://partizany.by/news/partizanskie-stikerpaki/> 09.05.2021.

Партизаны Беларуси $<$ https://partizany.by/> 09.05.2021.

«Присяга белорусского партизана». Наумова А. (ред.). Партизаны Великой Отечественной войны советского народа. Москва - Ленинград: Детгиз, 1941: 3.

Симонов Константин. «Убей его». Красная звезда 18.07.1942: 3.

«Слава советским партизанам!» Наумова А. (ред.). Партизаны Великой Отечественной войны советского народа. Москва — Ленинград: Детгиз, 1941: 4.

Чесноков Иван. «Речевой акт «Клятва»: эксплицитные перформативные высказывания». Известия Волгоградского государственного педагогического университета 3 (2016): 110-113.

Шестов Лев. Апофеоз беспочвенности. Москва: Librarium, 2018.

Шмитт Карл. Понятие политического. Санкт-Петербург: Наука, 2016.

Шмитт Карл. Теория партизана: Промежуточное замечание по поводу понятия политического. Шмитт Карл. Теория партизана. Москва: Праксис, 2007: 7-144.

Эренбург Илья. «Партизанские пули от сердца летят». Наумова А. (ред.). Партизаны Великой Отечественной войны советского народа. Москва — Ленинград: Детгиз, 1941: 15-17.

Эренбург Илья. «Убей!». Красная звезда 24.07.1942: 3.

Freudenberg, Dirk. Theorie des Irreguldren. Partisanen, Guerillas, und Terroristen im modernen Kleinkrieg. Wiesbaden: VS Verlag, 2008.

Kharkhordin Oleg. The Collective and the Individual in RussiaA Study of Practices. University of California Press, 1999.

Marder Michael. Groundless Existence The Political Ontology of Carl Schmitt. London: Blumsbury, 2010.

Shepherd Ben, Pattinson Juliette. "Introduction". War in a Twilight World. London: Springer, 2010: 1-23. Partisan and Anti-Partisan Warfare in Eastern Europe, 1939-45.

Urban Michael. An Algebra of Soviet Power Elite Circulation in the Belorussian Republic 1966-86. Cambridge: University Press 1989.

Wolin Richard. "Carl Schmitt, political existentialism, and the total state". Theory and Society 19 (1990): 389-416. 


\section{LITERATURE}

Alejchanka Yuliya. «Aposhnyae skazanae»: rytm i sens liryki Yanki Kupaly 1941-1942 gg.». Mova i litaratura: materyyaly 76 -j navuk. kanf. studentay̆ $i$ aspirantay̆ filalagichnaga fak. BDU, Minsk, 24 krasavika 2019 g. [pad red. K. A. Tananushki]. Minsk: BDU, 2019: $3-6$.

Apresyan Ruben. «Talion i zolotoe pravilo: kriticheskij analiz sopryazhennyh kontekstov». Voprosy filosofii 3 (2001). 72-84.

Arendt Hanna. Banal'nost' zla. Ejhman v Ierusalime. Moskva: Evropa, 2008.

Bartushka Mark (red.). Partyzanskaya vajna y̆ Belarusi y̆ 1941-1944 gg. Smalensk: Inbelkul't, 2014.

Belyaeva Elena. «Istoricheskoe formirovanie universalij morali». Moral' i universal'nost': $s b$. nauch. st. pod red. R. G. Apresyana. Moskva: Gumanitarij. 1 (2018): 195-212.

Belyaeva Elena. «Neotradicionalizm kak harakteristika sistemy nravstvennosti belorusskogo obshchestva». Vuchonyya zapiski Bresckaga universiteta: zb. navuk. prac. 9. Chastka 1. Gumanitarnyya i gramadskiya navuki, 2013: 15-21.

«Beseda o partizane». Karl Shmitt i Ioahim Shikel'. Teoriya partizana. Moskva: Praksis, 2007: $145-178$.

Bradenberger David. Nacional-Bol'shevizm. Stalinskaya massovaya kul'tura i formirovanie russkogo nacional'nogo samosoznaniya (1931-1956). Sankt-Peterburg: Akademicheskij proekt - Izdatel'stvo DNK, 2009.

Bykov Vasil'. Boloto. Druzhba Narodov 7 (2001) https://magazines.gorky.media/druzhba/ 2001/7/boloto.html 08.05.2021.

Bykov Vasil'. Sotnikov. Bykov Vasil'. Sobranie sochinenij. V 4 t. T. 2. Moskva: Molodaya gvardiya, 1985: 305-452.

Chesnokov Ivan. «Rechevoj akt «Klyatva»: eksplicitnye performativnye vyskazyvaniya». Izvestiya Volgogradskogo gosudarstvennogo pedagogicheskogo universiteta 3 (2016): $110-113$.

Duchyc Lyudmila, Lobach Uladzimir, San'ko Syargej. «Balota». Belaruskaya mifalogiya. Belaruskaya mifalogiya: Encyklap. sloy̆nik. Minsk: Belarus', 2004: 41-42.

Erenburg Il'ya. «Partizanskie puli ot serdca letyat». Naumova A. (red.). Partizany Velikoj Otechestvennoj vojny sovetskogo naroda. Moskva — Leningrad: Detgiz, 1941: 15-17.

Erenburg Il’ya. «Ubej!». Krasnaya zvezda 24.07.1942: 3.

Freudenberg, Dirk. Theorie des Irreguldren. Partisanen, Guerillas, und Terroristen im modernen Kleinkrieg. Wiesbaden: VS Verlag, 2008.

Gabrilovich Evgenij. "Geroicheskie zhenshchiny belorusskogo naroda» Naumova A. (red.). Partizany Velikoj Otechestvennoj vojny sovetskogo naroda. Moskva - Leningrad: Detgiz, 1941: 21-24.

Gajdar Arkadij. Voennaya tajna. Perm‘: Permskoe knizhnoe izdatel'stvo, 1959.

Gryakalov Nikolaj. «Lex talionis. K fundamental'noj antropologii taliona». Vestnik SanktPeterburgskogo universiteta. Filosofiya i konfliktologiya 2 (2015): 12-20.

Kharkhordin Oleg. The Collective and the Individual in RussiaA Study of Practices. University of California Press, 1999.

«Klyatva kurskih partizan na vernost' Rodine, sovetskomu narodu, pravitel'stvu i Kommunisticheskoj partii. 12 oktyabrya 1942 g.» < http://docs.historyrussia.org/ru/nodes/ 248943-klyatva-kurskih-partizan-na-vernost-rodine-sovetskomu-narodu-pravitelstvui-kommunisticheskoy-partii-12-oktyabrya-1942-g>09.05.2021.

«Klyatva partizan otryada im. «Pavla» Shahovskogo rajona Moskovskoj oblasti. Oktyabr' 1941 g.» $<$ http://docs.historyrussia.org/ru/nodes/178061-klyatva-partizan-otryada-im-pavlashahovskogo-rayona-moskovskoy-oblasti-oktyabr-1941-g> 09.05.2021.

«Klyatva, davavshayasya partizanami Odesskogo Prigorodnogo rajona pri vstuplenii v otryad. Yanvar' 1942 g.» <http://docs.historyrussia.org/ru/nodes/181012-klyatva-davavshayasyapartizanami-odesskogo-prigorodnogo-rayona-pri-vstuplenii-v-otryad-yanvar-1942-g> 09.05.2021.

Kolas Yakub. Adpomscim. Maskva: Vydanne gazety «Soveckaya Belarus’», 1942. 
Kovalenya Aleksandr, Stashkevich Nikolaj. Velikaya Otechestvennaya vojna sovetskogo naroda (v kontekste Vtoroj mirovoj vojny). Minsk: Izdatel'skij centr BGU, 2004.

Kuleshov Arkadij. «Komsomol'skij bilet»<https://stihi.ru/2011/11/07/9898>/ 07.05.2021.

Kulik Sergej. «Kategorii partizanskih otryadov v gody Velikoj Otechestvennoj vojny». Vestnik Novgorodskogo gosudarstvennogo universiteta im. Yaroslava Mudrogo 37 (2006): 58-60.

Kupala Yanka. «Belaruskim partyzanam». Belaruskim partyzanam. Maskva: Vydanne gazety «Soveckaya Belarus'», 1942: 11-14.

Kupala Yanka. «Padnyalasya Belarus'». Belaruskim partyzanam. Maskva: Vydanne gazety «Soveckaya Belarus'», 1942: 5-10.

Kupala Yanka. «Pay̆stay̆ narod». Belaruskim partyzanam. Maskva: Vydanne gazety «Soveckaya Belarus'», 1942: 15-16.

Kupala Yanka. «Hlopchyk i lyotchyk na vajne». Belaruskim partyzanam. Maskva: Vydanne gazety «Soveckaya Belarus'», 1942: 17-18.

Kurennoj Vitalij. «Teoriya partizana». [Rec. na knigu: Shmitt K. Teoriya partizana. Moskva: Praksis, 2007]. Neprikosnovennyj zapas 1 (2008): 275-278.

Litvin Aleksej (red.). Belarus' partizanskaya. Illyustrirovannaya enciklopediya partizanskogo dvizheniya v Belarusi v gody Velikoj Otechestvennoj vojny. Minsk: Belaruskaya Encyklapedyya imya Petrusya Broy̆ki, 2019.

Litvinova Ol'ga. «Evolyuciya partizanskoj etiki v gody Velikoj Otechestvennoj vojny (po materialam Bryanshchiny)». Yaroslavskij pedagogicheskij vestnik 1 (2016): 297-302.

L'yuis Sajmon. «"Partizanskaya respublika”: kolonial'nye mify i vojna za pamyat' v Belarusi». Novoe literaturnoe obozrenie $6(2020)<\mathrm{https}$ ://www.nlobooks.ru/magazines/novoe_literaturnoe obozrenie/166 nlo_6 2020/article/22957/>09.05.2021.

Marder Michaei. Groundless Existence The Political Ontology of Carl Schmitt. London: Blumsbury, 2010.

Melezh Ivan. Lyudzi na baloce: raman z «Paleskaj hroniki». Minsk: Mastackaya litaratura, 1991.

Musyal Bogdan. Saveckiya partyzany y 1941-1944 gg. Mify i rechaisnasc’. Smalensk: Inbelkul't, 2018.

Myunkler Gerfrid. Oskolki vojny. Evolyuciya nasiliya v XX $i$ XXI vekah. Moskva: Kuchkovo pole, 2018.

Nicshe Fridrih. Po tu storonu dobra i zla. Nicshe Fridrih. Polnoe sobranie sochinenij. V 13 t. T. 5. Moskva: Kul'turnaya revolyuciya, 2012: 9-228.

Partizanskij stikerpak <https://partizany.by/news/partizanskie-stikerpaki/>09.05.2021.

Partizany Belarusi $<\mathrm{https}: / /$ partizany.by/> 09.05.2021.

«Prisyaga belorusskogo partizana». Naumova A. (red.). Partizany Velikoj Otechestvennoj vojny sovetskogo naroda. Moskva — Leningrad: Detgiz, 1941: 3.

Simonov Konstantin. «Ubej ego». Krasnaya zvezda 18.07.1942: 3.

«Slava sovetskim partizanam!» Naumova A. (red.). Partizany Velikoj Otechestvennoj vojny sovetskogo naroda. Moskva — Leningrad: Detgiz, 1941: 4.

Shepherd Ben, Pattinson Juliette. "Introduction". War in a Twilight World. London: Springer, 2010: 1-23. Partisan and Anti-Partisan Warfare in Eastern Europe, 1939-45.

Shestov Lev. Apofeoz bespochvennosti. Moskva: Librarium, 2018.

Shmitt Karl. Ponyatie politicheskogo. Sankt-Peterburg: Nauka, 2016.

Shmitt Karl. Teoriya partizana: Promezhutochnoe zamechanie po povodu ponyatiya politicheskogo. Shmitt Karl. Teoriya partizana. Moskva: Praksis, 2007: 7-144.

Urban Michael. An Algebra of Soviet Power Elite Circulation in the Belorussian Republic 1966-86. Cambridge: University Press 1989.

Val'ke Anika. «Pamyat', gender i molchanie: ustnaya istoriya v (post-) sovetskoj Rossii i prizrachnaya gran' mezhdu publichnym i privatnym». Laboratorium. Zhurnal social'nyh issledovanij 1 (2011): 138-154.

Van Krevel'd Martin. Transformaciya vojny. Moskva: Al'pina biznes buks, 2005.

Wolin Richard. "Carl Schmitt, political existentialism, and the total state". Theory and Society 19 (1990): 389-416.

Zhelyazko Vladimir, Lagun Tihon, Lihacevich Anatolij «Razvitie sel'skohozyajstvennoj gidromelioracii v Belarusi». Prirodoobustrojstvo 4 (2016): 75-80. 
Андреј Дудчик

\section{НОМОС МОЧВАРЕ: КОНЦЕПТУАЛИЗАЦИЈА ПРОЈЕКТА БЕЛОРУСКЕ „ПАРТИЗАНСКЕ ЕТИКЕ“}

\section{Резиме}

У раду се реконструишу основни постулати „партизанског мита“ у белоруској култури из периода после рата, као важног елемента белоруског идентитета у сфери политичког и привредног живота, колективног и породичног памћења, система образовања и васпитања, масовне културе. Реконструишу се особености поимања „идеје о партизану“, имплицитно представљене у белоруским делима ратног и послератног периода. Показује се интересовање за етичко-егзистенцијалну проблематику, карактеристичну за белоруски „партизански наратив“: у ратном периоду - за тематику борбе с непријатељем и идеју освете, у послератном периоду - за идеју индивидуалног моралног избора у граничним ситуацијама. За означавање партизанске делатности у неодређеној ситуацији и у етичким проблемима који су у спрези с њом, предлаже се употреба метафоре „номос мочваре“ по аналогији с терминима познатог теоретичара партизанске борбе К. Шмита и услед значаја који представе мочваре имају у белоруској култури.

Кључне речи: партизанска етика, партизанска теорија, партизански покрет, Велики отаџбински рат, белоруска совјетска књижевност, белоруски идентитет. 